\title{
The Complex Process of Children's Identity in New Landscapes of Media and Culture
}

\author{
Ebba Sundin ${ }^{1}$ \\ School of Education and Communication, Jönköping University, Sweden
}

\section{doi:10.5937/comman1329017S}

Summary: Media's effects on children's behaviour and emotional status, as well as their vulnerability as Internet users and exposers are with no doubt two important areas within children and media studies. Nevertheless, research including children in the assumptions of media's role in everyday life needs to be emphasized. How children navigate in complex life worlds is of importance to many different research fields. Studies of media's role in children's lives will gain from including aspects of everyday life and notions of culture and identity processes. In order to understand the complexity of the modern landscapes of media and culture, the theoretical perspectives in this article are based on media and space, and how media influence cultures locally and globally. The aim is to discuss how children and adolescents reflect on culture and identity in their relationship to media. This discussion is based on two studies involving children in three disparate places, but with the similarities of having an extraordinary complex cultural and national structure: The Faroe Islands, Aland and Canada. The studies are based on different research methods, like interviews and text analysis. The findings suggest broader paths for the research of children and media for a deeper understanding of young media users' awareness of media's role in shaping and maintaining cultural identities.

Keywords: identity processes, children, media, cultural identity, national identity, globalisation, complexity

\footnotetext{
1 ebba.sundin@hlk.hj.se
} 


\section{Introduction}

The question of media's role in children's making sense of local or global cultural identities is complicated. Many children grow up in one specific local culture based on the geographical parameter within special borders of, for example, a nation or a region. Geographical locations with natural borders such as water, mountains and climate shape the specific characteristics of the local identity. Historical parameters, for example family origins belonging to other or mixed cultural identities will make the picture more complex, especially in the discussion of new generations as 'citizens of the globe'.

Positive and negative aspects of media in children's lives cannot be studied without adding the complexity of everyday life. Children have the ability to communicate across cultural borders and they have access to participate in borderless media cultures. Depending on the content and what sense it makes to children we can discuss benefits or losses for the individual user. The aim of this article is to discuss some findings within the complex research area of children, media and processes of cultural identity. The article is based on the following overall research question: How do children and adolescents reflect on culture and identity in their own relationship to media?

In order to understand the complexity of the modern landscapes of media as well as culture, the article will frame the overall question with theoretical perspectives on media and space and how media influence cultures locally and globally.

\section{Children from the North}

In the article, the conclusions of this complex process of children's identity being shaped in the multi-layered media landscape are based on two separate studies. The first study includes interviews with teenagers growing up in two of the autonomous territories of the Nordic Region, and the second study includes content analysis of published articles by children reporters in Toronto, Canada. From both studies we can learn about how children reflect on culture and identity from their own use of media, and that is the reason for presenting them together in this article about children's identities in new media and culture landscapes. What the two autonomous territories in the Nordic Region have in common with Canada is that they share, although different from each other, an 
extraordinary complex cultural, national and geographical location. The studies are not presented as comparisons, because the methods are different and the age groups are different. Instead, the studies are presented as complements to give a broader understanding of the complex processes of children's identity in the new media landscape.

In the first study, teenagers living in The Faroe Islands and Åland tell about their media habits in everyday life. The study has an ethnographic approach with some observations but particularly qualitative interviews. In total eight teenagers, aged 15-16, were part of the study conducted during the years 20102012. The ethnographic approach in this study can best be explained by the focus of the research questions. The overall issue for the study was to develop a deeper understanding of media's role in children's lives while growing up in areas with no natural national borders, and therefore a more complex landscape of culture and media. The basic assumption of media has been its role in everyday life for the teenagers, here as well as elsewhere in the world. From an ethnographic perspective, the routines in everyday life are usually taken for granted and not very much reflected on (Machin, 2002).

One way to detect media's role in everyday life is to conduct interviews with questions about media habits and let the respondents reflect on media use in connection to sense of belonging. This discussion is also influenced by the role of language since "it often includes the identification or marking of social categories, the embodiment of socio-political ideologies, the maintenance and manipulation of individual social relationships and networks, and various means of effecting social control" (Saville-Troike, 2003: 30). If respondents have a chance to choose media of different languages, this may also be a strong influence on identification and cultural belonging. The interviews took place in Torshavn, the capital of the Faroe Islands, and Mariehamn, the capital of Åland. These were the cities the teenagers lived in and therefore the most natural place to meet them for interviews.

Study number two is based on content analysis of published articles, written by Canadian children. The methods of this study can be described as a media discourse analysis, with a focus on the cultural expressions. The young writers live in a country where the American media culture for years has been influential. But also, multiculturalism has been a strong value in Canadian politics 
since it was introduced as an official policy by the Canadian government in 1971.

During the years 2003-2006, the daily newspaper The Toronto Star published a children's weekly newspaper, The Brand New Planet as a project to reach one-third of children in the age group and living in the Great Toronto Area. Children were invited to write for the paper and a large number of children were involved in writing articles, columns and reviews for the paper. Some children wrote on a continuous basis and also participated in regular editorial meetings. During the school semesters, the paper was published on Thursdays and sent to schools, homes and children-orientated places like libraries and recreational centres. In total 100.000 copies were distributed every week. This study is based on a sample of feature articles, columns and reviews including a total of more than 2.000 items written by 9 to 14 -year-old children.

The expressions of the young writers' own cultural belonging and sense of the Canadian environment have been at target. From the critical discourse analyses' standpoint, the language of media are embedded in the assumption of power (Fairclough, 1995). On the other hand, Richardson (2007) states that journalism helps people to better understand their reality. Cotter (2010) defines media discourse analysis (MDA) as a combination of different traditions within discourse analysis and ethnography. With this gaze in mind, the study of children's writing aimed at detecting cultural notions of themselves and their society, in this case Canada. Therefore, the method used are best described as media discourse analysis where the texts has been analysed from a qualitative approach, searching for the practices of collective identities in a country with layers of both multicultural and a national identities.

\section{Communication, media and culture}

Communication in relation to time and space has been on the theoretical agenda for a long time. In the wake of the introduction of new communication technology followed a stronger theoretical assumption on society, as it changed to become more borderless. One of the keywords during the 1990's and the beginning of 2000's, not only in the field of media and communication studies, was globalisation. Among media and communication scholars as well as sociologists, one of the core issues of the globalisation process was and still is the impact on national and cultural identities. Castells (2009: 117) talks 
about cultural globalisation as "a specific set of values and beliefs that are largely shared around the planet", but in the same time these values are contradicted by "specific sets of values and beliefs in which specific human groups recognize themselves", formed by, for example, history and geography. In many of the theoretical works on globalisation, the discussion has its starting-point from a macro level, including the flows of communication, economy and culture and their impacts on global and national identities (see for example Anderson, 1983; Giddens, 1991, 2002; Thompson, 1995; Baumann, 2000, 2005; Rantanen, 2002, 2005; Castells, 1996, 1997, 1998, 2009; Deuze, 2007; Watson, 2008; Kavoori, 2009; Ferguson and Mansbach, 2012).

Another aspect is the individual level, i.e. the micro level of identity, and how globalisation gives individuals opportunities to make their own choices of belonging to cultures with no boundaries in space. Within the research field of media and children and adolescents, one of the newer paths to stress is the rise of the generation where the mobile communication plays an important role in defining culture. For example, Caron and Caronia (2007: 18) state that the shift is from "localized identity" to "delocalized identification". The concept of mobile cultures does not solely include the ability to communicate and have access to media content everywhere. It also includes the ability of being part of the 'other' realities on the Internet, for example, being and identifying with an avatar in an on-line game community, or as a "youthful cyberflâneurs [who] uses information and communications technologies (ICTs) as tools for inquiry, and digital technologies for the production of visual and written commentary and critique" (Kenway and Bullen, 2008: 24). The borderless media realities are part of the globalisation, and according to Rantanen (2002: 7) a challenge to "the process of national identity-building" because of the competition of alternative identities.

In the same time there is another aspect on global communication to weigh into the discussion. When the mass production on media content started more than a century ago, the concern was that some dominant media producers would overwhelm other parts of the world with new cultural ideas. In early media research, this was not referred to as globalisation but cultural imperialism. The critique was especially targeting the strong media producers in the western world. The NWICO (New World Information and Communication Order) debate, initiated by UNESCO in 1970, was an example of trying to 
balance the international media flow, particularly when it came to the world images based on news coverage. In modern research about global media flow, the assumptions of imbalance of cultural representations may be similar as the NWICO debate, but they can also be in the guise of praising a homogeneous global media culture. No matter if the assumptions are positive or negative, some media scholars turn their back on the idea of globalisation as a powerful force in weakening cultures of nations and regions. Instead, they claim that nations still play an important role for the communication flow (Curran and Park, 2000; Lee et al., 2005; Tunstall, 2010).

This important role can be interpreted as nations' roles to form the communication within specific borders, geographical or political. Media content will be presented according to the standards within this nation, and these are built up by history, politics, culture, etc. The question of the role of the nation when it comes to the global communication flow is more complex because nations are far from fixed, and from one point of view built on collective and imagined identities (Anderson, 1983). Media do not only present these images of a nation, but are also active in changes (Mihelj, 2004).

While national identity is built by shared ideas of culture, history and language, where media play an important role, the media also contribute to individual identity building. According to Weedon (2004), the media encourage identification on individual terms. This is also an important notion by Thompson (1995) in his dichotomy of "self-identity" and "collective identity", the latter referring to shared identities of nations or cultures in the same path of ideas as Anderson (1983). Although the two types of identities collaborate in the sense that media may delocalize certain traditions, according to Thompson, the media also contribute to maintain traditions. This is part of what Thompson (1995: 203) calls "a cultural landscape in the modern world of enormous complexity and diversity". In this landscape Thompson also recognizes "mediated microworlds" where individuals live more or less temporarily depending on choices of interests. Clearly, Thompson was early in his analysis of the complex cultural landscape just at the beginning of the communication technology developments.

From the perspective of global identities, media play an important role in the collective understanding of phenomenon beyond physical reach. This understanding can contribute to the shaping of global identities. In the same 
time, media also shapes symbolic forms of stereotypes. This can express the opposite contribution from the media in a negative way. The own identity can be strengthened by the media content about phenomenon beyond the physical reach and also exclude the recognition of other cultural identities (Gripsrud, 2002).

To summarize the theoretical assumptions within media and communications after the digitalization of the media landscape, one might give the following description. Some scholars have their focus on the processes of global cultures and its impact on individuals, children and adolescents as well as adults, and other scholars are more concerned in acknowledging national boundaries in the on-going process of shaping individuals' sense of cultural belonging. Altogether, the two perspectives do not challenge each other and are not necessarily contradictory. They show the complex process of globalisation and its effects on defining identify in the new landscapes of culture and media. The reason for this is that both the landscapes of culture and media are extremely complex in themselves, not only because of their multi-layers of components but also because of the variety of theoretical perspectives and assumptions on how to define culture and media.

However, one important aspect should not be forgotten, and that is the recognition of the thought that technology separated space and communication long before the digital breakthrough. Carey (1989) argued that the telegraph in the $19^{\text {th }}$ century had a large impact on communication changes in society leading to changes of cultural mindsets. Before Carey, in the 1950's and 60's, the Canadian scholars Innis $(1950,1951,1952)$ and McLuhan $(1951,1962,1964)$ developed theories deeply involving the relationship between communication and culture, as well as communication, time and space. In the last work of Innis from 1952, media's effect on culture is not only a point taken, but stated as a threat. In his introduction to Changing Concepts of Time, he writes: "In radio and in television accessibility to American stations means a constant bombardment of Canadians. [...] The effects of these developments on Canadian culture have been disastrous. Indeed they threaten Canadian national life" (Innis, 1952/2004: 12-13).

The issue of too much American media influence has been on the social agenda, as well as the research agenda in Canada for a long time. Although, Canada is not the only country where the American media have had a strong 
influence. For example in European countries, the debate of American media content has been on the agenda with special regulations to promote content with the own cultural identification.

\section{Children in the digital culture age}

The research field of children and media has another complex dimension that needs its own address in every study, namely the position of how childhood is interpreted. According to Prout (2008: 21), one of the major concerns for researchers in this particular field is "the constitution of childhood as a phenomenon and the problem of studying its complexity, heterogeneity and ambiguity". In earlier studies of children and media, children were often in the position of being objects of the research. In the same time the research often had a strong normative approach, just like the ongoing public debate. Then the interpretation of what constructed childhood changed towards an approach where children's abilities to make their own judgements and sense-making were acknowledged, mainly from a sociological point of view. Christensen and James (2008) talk about a paradigm shift in childhood research from objects to subjects. This view within childhood studies is also shared by Qvortrup (2008) who reasons the variability of studying childhood be compared to the same discussion by Prout (2008) about complexity.

Some of the major impacts to the paradigm shift in childhood studies that also came to influence many media and children scholars were the theoretical works of James and Prout (1997) and James, Jenks and Prout (1998), about reconstructing and theorizing childhood. One way to illustrate the changes in both research and the public debate is to go from the publishing of Neil Postman's The Disappearance of Childhood (1982) to David Buckingham's After the Death of Childhood (2000). Within the field of children and media studies, Livingstone has carried on the tradition of the new paradigm, in some studies combined with the issues of children's vulnerability of the changing media landscape (Livingstone, 2009; Livingstone and Haddon, 2009).

Media's negative effects on children's behaviour and emotional status as well as their vulnerability as Internet users and exposers are with no doubt two important areas within children and media studies. Nevertheless, research including children in the assumptions of media's role in everyday life needs to be emphasized as well. How children navigate in complex life worlds is of im- 
portance to many different research fields. Media are often neglected as one of many factors that shape understanding and meaning in everyday life, and are only at target if negative outcomes are expected. One example is the research of children and socialization. At first, media as a social agent were not acknowledged at all. In a literature overview, Rosengren and Windahl (1989) came to the conclusion that the role of media and mass communication are acknowledged in the general research of socialization but few studies were to be found. As an example of this, they point at Goslin's Handbook of Socialization Theory and Research from 1969, a handbook of 1,200 pages with the devotion to mass communication stretched to half a page.

Since the 1980's, the media have been recognized as one of many agents in the socialization process (DeFleur and Ball-Rokeach, 1989; McQuail, 2010; Rosengren and Windahl, 1989). According to McQuail, the view on media's role in socialization is two-folded: "[...] on the one hand, the media can reinforce and support other agencies of socialization; on the other, they are also viewed as a potential threat to the values set by parents, educators and other agents of social control" (McQuail, 2010: 492). Although studies about the relationship between children and media have a tendency to emphasize on negative effects, there are some areas of research where media are seen to be of value in children's lives. Some of the positive effects are mentioned by McQuail like the following: "[...] learning about the wider world, educational effects, and help in forming an identity" (McQuail, 2010: 484).

Media's involvement and role in young people's lives have been on the adults' agenda for almost a century, often blaming media to promote de-moralization among the young generations. The media history shows many examples of how the threat has been emphasized in the debate and sometimes connected to the media research, from the early development of the film industry to modern digital media content. In some cases, the users articulated the ideas behind the media innovations, not the producers. For example, in the 1950's the portable shirt-pocket radio became a popular tool for young American rock ' $n$ ' roll music lovers because their parents would not approve the listening of this new and morally threating music genre (Gronow, 2009).

In modern times a big portion of the focus has been on new digital media forms and threats to children and adolescents. However, some research has been 
focused on the opportunity of new media when it comes to engagement and participation in society, also from the view of young citizens.

The understanding of how children and young people reason about everyday life in their relationship to media and what it says about their sense of belonging in the paradigm of mobile cultures, digital nomads and net generations, has not been strongly emphasized in the field of media research. There are some exceptions though, and these are of specific interest for the studies presented in this article. The changing media environment and its impact on children growing up in Greenland has been followed in several research projects (Rygaard, 2008). The conclusions of these projects are that globalisation trends have led to positive changes for children growing up in what could appear to be an isolated place like Greenland.

The two studies presented in this article might complement previous studies and bring out more understanding on how children orientate in the complex local and global landscape of culture and media.

\section{Reflections on Media and Belonging}

Within the Nordic Region, there are three autonomous territories belonging to Denmark (Greenland and The Faroe Islands) and Finland (Åland). The Faroe Islands and Alland are two similar territories in the perspective that they are located at sea, consisting of islands. The Faroe Islands are located in the Atlantic Ocean between the British Isles and Iceland, while Åland is located in the Baltic Sea between Sweden and Finland. In total, the population of the two territories is 80.000 . The official languages differ from the countries they belong to; in the Faroe Islands the inhabitants speak Faroese and in Aland they speak Swedish. The political and cultural history of the two territories are naturally different but the people share the same kind of history involving fights for independence, or at least a less imposed influence from the countries they are part of. For a long time the issues of cultural independence and identity have been strong, and the media have played a strong role in these matters. Both territories have their own media structure with local newspapers, Public Servicechannels in TV and radio (in this case following the strong tradition of Public Service within the Nordic Region), and commercial media along with the new formats of digital media. 
From this introductory background, the media and cultural landscapes in The Faroe Islands and Åland can be described as complex. Children grow up with the strong roots of the cultural history of the islands, but in the same time they are part of cultures in the countries they belong to or are close to, as well as the global communication society.

The following quotation from an interview with a 15-year-old girl gives an idea of how the cultural identity can be expressed in Åland:

The only occasion when I think Finland really counts... is when there is a tournament in hockey. Otherwise, people are more oriented towards Aland itself or the relationship between Aland and Sweden.

Other teenagers express a more complicated view on what appears to be a simple choice in tournaments and contests. For example, another girl has a more complex attitude, saying that it is difficult when Sweden and Finland are in hockey games against each other, because she does not know which national team she should favour. But she agrees that the most common in Åland would be to favour Finland. She also mentions when Finland won the Eurovision Song Contest some years ago she was very happy, but also when Sweden won in 2012. She is also aware of the impact of media when it comes to her own sense of belonging:

I have said many times that I feel more Swedish than Finnish because of media; radio, TV and all these things making me feel like a Swede.

The sense of being part of Europe seems stronger among the interviewed teenagers in Åland than The Faroe Islands. Below are two examples of how teenagers in the Faroe Islands reflect on their sense of belonging outside the islands. The first quote is by a girl and the second by a boy, both 15 years old:

No, I don't even think I am in Europe. It [The Faroe Islands] is just such a small country. It feels like we are just a forgotten country hidden in a corner.

I feel that we are more a part of the Nordic region, Scandinavia, and not so much Europe.

Teenagers growing up in the territories share many media habits. It does not matter if living in The Faroe Islands or Åland, the attraction to American TVseries is the same. When asked about TV watching, the main interest was crime 
or drama series as well as reality-TV series. The use of social media was also a shared interest, especially the use of Facebook. But they used it to communicate with near-by friends. For some of the teenagers in the Faroe Islands who had lived in Denmark, they also included some of their Danish friends. When it came to the question of extending the friends circle to people only met on the Internet, they all turned this down. To them, Facebook was for "real" friends. This Faroese girl represents the view of most of the interviewed teenagers:

I only have people who I know and people I see regularly. Not anyone I found on the Internet. I don't like that.

The interest of local news is low and they do not pay much attention to their local newspapers or news reports on TV or radio. The overall image is that not very much is happening at home, but when it does, then they turn to local media. Some of the teenagers were aware of the importance of local media and that they would start read newspapers when they grew older. It was clear that the teenagers in Åland took part of Swedish media to a greater extent than the Finnish media. One reason for this was the language issue. Also, Finnish news was connected to school work and something they discussed during classes in Current Events.

The study of media's role in the lives of teenagers growing up in The Faroe Islands and Åland did not have the ambition of comparing and stressing differences between the two territories. Although, one striking difference between the areas is the teenagers' relationship to the language, and especially their native tongues. The teenagers in The Faroe Island have their own language, not spoken outside the territory. It is used in everyday life; in discussion with family and friends, but they don't consider their native tongue much of a media language. Books are normally read in Danish or English, because the Faroese language is too difficult to read. Two of the teenagers gave the following views of their native tongue:

I talk Faroese, but when it is written it is so old-fashioned kind of, it is boring.

\section{I think we are the only country that knows what Faroese is.}

The teenagers in Åland have a different relationship to their native tongue, since it is also the native tongue of the neighbour country, with the effect of stronger cultural links to Sweden like mentioned above. 
To summarize, the teenagers interviewed in the two autonomous territories in the Nordic Region gave a rather complex picture of how they navigated in the media landscape. Their media habits are based on different levels from their own local media to media in other languages. In the same time, their media habits are similar to teenagers' media habits around the world. Digital media is part of the everyday use of communicating and finding information on all levels.

\section{"Canada invaded and stormed"}

Contrary to the two autonomous territories within the Nordic Region, geographically, Canada is the second-largest country in the world. Stretching between two oceans, the Atlantic and the Pacific, the distance is so great, it takes about a week to drive from one coast to the other. Circa 35 millions live in Canada, only about one-tenth of the population in the neighbouring country, USA. Canada's cultural position within its national borders is somewhat complex. The population consists of many different cultural groups since Canada shares the American history of immigrants moving to the North American continent to find a better life, especially from the late $19^{\text {th }}$ century and onwards. There are two official languages in Canada: English and French. Canada is often described as a multi-cultural nation.

Certain patterns appear in the way the young writers express their images of their own country and culture. There is no doubt that the writers are aware of the freedom of speech as part of the Canadian society. Some subjects are more prone to be criticized like politics and media. The young writers also show a strong awareness of protecting the cultural identity of Canada. Expressions of protection can be detected by word use, for example verbs like invaded and stormed:

$M T V$ is the new reality heaven. The network recently stormed Canada, sweeping up many American MTV shows and dumping them on Canadian soil. (Boy reporter, 13 years old, Issue \# 130: MTV Canada: breath of fresh reality)

The American media are under scrutiny by the young writers and with a sensitivity of pointing out that the productions of media content are not the 
same in USA and Canada. The following example shows this awareness of cultural differences when the young writer rewrites a new American show:

[...] what would it be like if we had our own Canadian Dad show... Stan will go to extremes to protect his beloved Canada from harm - as evidenced by his terrorist colour-coded bacon that is served up at the local greasy spoon. (Boy reporter, 13 years old, Issue \# 93: What if American Dad moved north?)

Another example of dealing with American and Canadian TV content is an article about the comparison of two popular teen series, O.C. (American) and Degrassi: The Next Generation (Canadian). When it comes to reality the two girl reporters came to the conclusion that Degrassi was very realistic, while O.C. was "a little less realistic" and the reasons for this was that everyone of the characters in the American series were "beautiful, rich, has big houses, perfect friends, problems are always concerned with love etc." (Girl reporters, 14 years old, Issue \# 90: Degrassi vs. O.C.).

It is also obvious that the young writers acknowledge their own culture to be part of the North American, and therefore, the threats are not always coming from the neighbour country. Sometimes, American phenomena are treated as their own. For example, when two 12-year-old girls write about the establishment of the Swedish clothing company H \& M in Canada, its popularity in Europe is compared to "their" Gap, an American clothing company (Issue \# 50: H\&M invades T.O.). In the following example, we see that the writer is a bit inconsistent in his references to Canadians and Americans:

This may sound funny, but some tourists from Toronto and New York wore their parkas around the resort. The average temperature at the time was only around 12 degrees Celsius, but with the wind it felt even colder. This may sound even funnier, but the Mexican hotel staff continued to wear their short-sleeve Hawaiian style shirts. The staff can handle the cold better than us Canucks! (Boy reporter, 13 years old, Issue \# 44: Sun, sea and sand traps)

Another example is connected to the Winter Olympic Games in Turin, Italy in 2006. Two twelve-year-old girls give some language tips for travellers:

Io sono Canadese/Americana (I am Canadian). If ever approached by a police officer or important official, this is very good to know. Keep in 
mind Italians may understand Americana better than Canadese. (Girl reporters, 12 years old, Issue \# 120: Italiano!)

The girls also recommend readers to be polite since they represent their generations of Canadians when travelling to other countries. In the same issue, an article about the Olympic athletic gear shows strong evidence in the reflections of nationalism and culture:

Thiscollectionwasdesigned by Canadians, producedby Canadiansandmadefor Canadians. Finallysomethingall-CanadianforsuchanAmerican-influencedculture. (Girl reporter, 12 years old, Issue \# 120: Patriotic gear fit for the podium)

Children's awareness of their own identity and sense of belonging are expressed in many of the articles. It is especially outspoken in articles concerning media, but also found in articles about politics, market, and environmental issues. When the children wrote about other cultures they tended to make references to their own experienced culture as well.

To summarize, children's awareness of media's role in order to identify their own culture and cultural belonging was clearly notified in their statements, both in the interviews and in the writings of the children. In the next and concluding part of the article, the findings will be further discussed in the light of children's identity shaping in the complex landscapes of media and culture.

\section{Conclusions}

The cultural landscapes will always be different from one place to another. The landscapes might be different within the place as well. Depending on history, ethnicity, shared identities with groups etc. the landscapes are complex and never static. The media has its role in both maintaining and changing structures of them, and when it comes to promoting or rejecting identification among individuals: children, adolescents and adults.

The cultural landscapes of the Nordic autonomous territories, The Faroe Islands and Åland, are very different. Compared to the Canadian cultural (multicultural) landscape, the two territories might appear homogenous. All the three areas presented in this article have their differences, but they also have similarities in that they can be described as extraordinary complex in their cultural, national and geographical locations. The territories and Canada are examples of 
cultural landscapes where the cultural awareness is high. This can be explained by the complexity of nationally and culturally belonging to other countries, while in the same time striving for maintaining a cultural status of its own.

From the perspective of media research when global media flow is either embraced or banned, it is easy to forget that the media landscape is also very complex. Lately, children and adolescents have often been referred to as 'citizens of mobile cultures', 'citizens of the globe' 'digital natives' or 'the on-generation' etc. At the same time, the structural layers of media are ubiquitous in many young people's everyday life. For example, they might not focus on the local news, but they are quite aware of its existence and its importance, at least for the 'grown-ups'. Children in the territories and Canada show that they are well aware of their own complex disposition and there are no hints in their statements that they solely identify with any homogenous global media culture.

In this article, the teenagers' reflections on media and the young writers' expression on culture add some valuable insights to the theoretical framework of media's role of making sense of global and local aspects of the world, as well as media's contribution to the individual sense of belonging.

These findings suggest broader paths for the research area of children and media. These paths can contribute to more understanding of how children and adolescents make sense of media and what output media might have when it comes to young media users' shaping of images of existing cultural identities. The autonomous territories in the Nordic Region and Canada are only examples of complex cultural and national structures. Therefore, it would be of great interest to develop larger and comparative studies of how children orientate in their everyday lives and what impact they believe media have, both locally and globally. I suggest a greater emphasis on studies of children and their relation to the local media landscape as well as the global, and especially in the comparative light between more and less complex cultural landscapes.

By acknowledging the complex structures of media the processes of identity can be studied for a better understanding how children and adolescents orientate in their own cultural landscape on an everyday basis. This includes the recognition of the layers, stretching from the local to the global media formats, as well as stretching from interpersonal to mass communication contents.

The point is that the research field would gain from a broader perspective of theoretical assumptions on media's role for children and adolescents in 
times of constantly developing communication technologies. Instead of a onesighted view claiming that the mobile culture is a new phenomenon occurring especially among the young generations, there is a need to bring in the history of the media field, and confirm that the mobile culture has been around for a long time. Carey (1989) was not wrong when he proposed that the major shift in communication and culture came with the telegraph. When communication was not physically bound with time and space, the big communication revolution occurred. McLuhan (1964/2001) was on the same track in the 1960's when he dealt with his idea of "the global village". Anderson (1983) and Thompson (1995) did not pay special attention to children or adolescents, but their theories could still be useful in the studies on how young people make sense of the world as well as make sense of their belonging in society and special cultural environments.

This also brings us to the concepts of socialization. In the new landscapes of media and culture the complex processes of how individuals identify themselves with their local and global societies and cultures are not only a question within the research of children and adolescents, but also adults.

\section{References}

Anderson, B. (1983/2006). Imagined Communities. $2^{\text {nd }}$ rev edition. London: Vergo.

Baumann, Z. (2000). The Individualized Society. Oxford: Polity Press.

Baumann, Z. (2005). Liquid Life. Oxford: Polity Press

Buckingham, D. (2000). After the Death of Childhood: Growing Up in the Age of Electronic Media. London: Polity Press.

Carey, J. W. (1989/2008). Communication as Culture. $2^{\text {nd }}$ rev ed. London: Routledge.

Caron, A. H. \& Caronia, L. (2007). Moving Cultures. Mobile Communication in Everyday Life. Montreal: McGill-Quenn's University Press. 
Castells, M. (1996). The Rise of the Network Society: The Information Age: Economy, Society and Culture, Vol. I. Oxford: Blackwell (2 ${ }^{\text {nd }}$ edition, 2010. Chicester: Wiley-Blackwell).

Castells, M. (1997). The Power of Identity: The Information Age: Economy, Society and Culture, Vol. II. Oxford: Blackwell ( $2^{\text {nd }}$ edition, 2010. Chicester: Wiley-Blackwell).

Castells, M. (1998). End of Millenium. The Information Age: Economy, Society and Culture, Vol. III. Oxford: Blackwell ( $2^{\text {nd }}$ edition, 2010. Chicester: Wiley-Blackwell).

Castells, M. (2009). Communication Power. Oxford: Oxford University Press.

Cotter, C. (2010). News Talk. Investigating the Language of Journalism. Cambridge: Cambridge University Press.

Christensen, P. \& James, A. (2008). Research with Children: Perspectives and Practices. Abingdon: Routledge.

Curran, J. \& Park, M-J. (2000). Beyond Globalization Theory. In Curran, J. \& Park, M-J. (eds.). De-Westernizing Media Studies. London: Routledge, pp. 3-18.

DeFleur, M. \& Ball-Rokeach, S. (1989). Theories of Mass Communication. White Plains: Longman.

Deuze, M. (2007). Media Work. Cambridge: Polity Press.

Fairclough, N. (1995). Critical Discourse Analysis. The Critical Study of Language. Harlow: Pearson Education Ltd.

Ferguson Y. H. \& Mansbach R. W. (2012). Globalization. The Return of Borders to a Borderless World? Abingdon: Routledge.

Giddens, A. (1991). Modernity and Self-Identity. Palo Alto: Stanford University Press.

Giddens, A. (2002). Runaway World. How Globalization Is Reshaping Our Lives. London: Routledge.

Gripsrud, J. (2002). Understanding Media Culture. London: Arnold.

Gronow, J. (2009). Fads, Fashion and 'Real' Innovations: Novelties and Social Change. In Shove, E., Trentmann, F. \& Wilk, R. (eds.), Time, Consumption and Everyday Life. Practice, Materiality and Culture. Oxford: Berg, pp.129-142. 
Innis, H. A. (1950/2007). Empire and Communication. Oxford: Oxford University Press. (4 ${ }^{\text {th }}$ edition, 2007 by Lanham: Rowman $\&$ Littlefield Publishers).

Innis, H. A. (1951/2008). Bias of Communication. Toronto: University of Toronto Press. ( $2^{\text {nd }}$ ed. Reprinted 2008).

Innis, H. A. (1952/2004). Changing Concepts of Time. Toronto: University of Toronto Press. (Rowman \& Littlefield edition, 2004 by Lanham: Rowman $\&$ Littlefield Publishers).

James, A. \& Prout, A. (1997). Constructing and Reconstructing Childhood. London: Falmer Press.

James, A., Jenks, C., \& Prout, A. (1998). Theorizing Childhood. Cambridge: Polity Press.

Kaavori, A. (2009). The Logics of Globalization. Plymouth: Lexington Books.

Kenway, J. \& Bullen, E. (2008). The Global Corporate Curriculum and the Young Cyberflâneur as Global Citizen. In Dolby N. \& Rizvi F. (eds.), Youth Moves. Identities and Education in Global Perspective. New York, N.Y.: Routledge, pp. 17 - 32

Lee, C-C., Chan, J. M., Pan, Z., \& So, C. Y.K. (2005). National Prisms of a Global 'Media Event'. In Curran, J. \& Gurevitch, M. (eds), Mass Media and Society. London: Hodder Arnold, pp. 320-335.

Livingstone, S. (2009). Children and the Internet. Cambridge: Polity Press.

Livingstone S. \& Haddon, L. (eds.) (2009). Kids Online. Bristol: The Policy Press.

Machin, D. (2002). Ethographic Research for Media Studies. London: Arnold. McLuhan, M. (1951/2008). The Mechanical Bride. Folklore of Industrial Man. New York: The Vanguard Press. (Gingko Press edition 2008 by Berkeley: Gingko Press).

McLuhan, M. (1962). The Gutenberg Galaxy. The Making of Typographic Man. Toronto: University of Toronto Press.

McLuhan, M. (1964/2001). Understanding Media. The Extensions of Man. New York: McGraw Hill. (2 ${ }^{\text {nd }}$ rev. ed. 2001 by London: Routledge)

McQuail, D. (2010). McQuail's Mass Communication Theory. London: Sage. Mihelj, S. (2004). Negotiating European Identity at the Periphery: Media Coverage of Bosnian Refugees and 'Illegal Migration'. In Bondebjerg, I. \& 
Golding, P. (eds.), European Culture and the Media. Bristol: Intellect, pp. 165-189.

Postman, N. (1982). The Disappearance of Childhood. New York, N.Y.: Vintage Books.

Prout, A. (2008). Culture-Nature and the Construction of Childhood. In Drotner, K. \& Livingstone, S. (eds.), The International Handbook of Children, Media and Culture. London: Sage, pp. 21-35.

Qvortrup, J. (2008). Macroanalysis of Childhood. In Christensen, P. \& James, A. (eds.), Research with Children: Perspectives and Practices. Abingdon: Routledge, pp. 66-86.

Rantanen, T. (2002). The Global and the National. Lanham: Rowman \& Littlefield Publishers.

Rantanen, T. (2005). The Media and Globalisation. London: Sage.

Richardson, J. E. (2007). Analyzing Newspapers. An Approach from Critical Discourse Analysis. Basingstoke: Palgrave MacMillan.

Rosengren, K. E. \& Windahl, S. (1989). Media Matter. TV Use in Childhood and Adolescence. Norwood: Ablex Publising Corp.

Rygaard J. (2008). Let the World In! Globalization in Greenland. In Drotner, K. \& Livingstone, S. (eds.), The International Handbook of Children, Media and Culture. London: Sage, pp. 254-270.

Saville-Troike, M. (2003). The Ethnography of Communication. An Introduction. Oxford: Blackwell Publishing.

Thompson, J. B. (1995). Media and Modernity. A Social Theory of the Media. Cambridge: Polity Press.

Tunstall, J. (2010). Anglo-American, Global, and Euro-American Media versus Media Nationalism. In Thussu, D. K. (ed.), International Communication. Abingdon: Routledge, pp. $239-244$.

Watson, J. (2008). Media Communication. An Introduction to Theory and Process. Hampshire: Palgrave MacMillan.

Weedon, C. (2004). Identity and Culture. Narratives of Difference and Belonging. Maidenhead: Open University Press, McGraw-Hill Education. 